\title{
EFFECT OF SCARIFICATION, SELF-INHIBITION, AND SOWING DEPTH ON SEED GERMINATION OF Lupinus campestris
}

\author{
Pedro Gutiérrez Nava ${ }^{1}$, Fernando De León González ${ }^{2 *}$, Jorge Etchevers Barra ${ }^{3}$, \\ and Alejandro Casas Fernández ${ }^{4}$
}

\begin{abstract}
Lupinus campestris Schltdl. \& Cham. grows in shallow fields and disturbed areas of Central Mexico. It has potential to improve soil fertility and as fodder. Seeds of L. campestris show dormancy, and the technology needed to increase its potential use requires information about conditions favouring seed germination. The aim of this study was to evaluate the seed germination response of L. campestris under controlled (laboratory) and natural field conditions. Under laboratory conditions, 2 yr old seeds had a maximum germination percentage (50\%) when they were scarified with sulphuric acid for 90 min prior to sowing and when laboratory light $\left(0.5 \mu \mathrm{mol} \mathrm{m}^{-2} \mathrm{~s}^{-1}\right)$ was maintained during the diurnal period. Without scarification, only about $3 \%$ of the seeds germinated. Light in laboratory resulted in an increased seed germination as compared to darkness condition. In the field experiment 1 yr old seeds were used testing the following treatments: (a) seed scarification (seeds scarified by 30 min immersion in sulphuric acid vs. not scarified), (b) presence or absence of plants of L. campestris in plots before field experiments, and (c) sowing depth (on soil surface and at $3 \mathrm{~cm}$ deep). The scarified seeds showed a germination percentage range between 50 and $64 \%$, whereas non-scarified seeds had 9 to $16 \%$ germination. The seeds sowed in plots with or without plants of $L$. campestris (before the experiment) germinated similarly, indicating no evidence of self-inhibition of germination. Three conclusions come out: (1) Scarification treatment with sulphuric acid effectively breaks dormancy in $L$. campestris seeds; (2) Direct sowing of scarified seeds (on the soil surface or at $3 \mathrm{~cm}$ depth) resulted in a range of $50-64 \%$ of germination under field conditions; and (3) no evidence was obtained for self-inhibition or a positive interaction between preceding vegetation and seed germination of L. campestris.
\end{abstract}

Key words: Seed dormancy, sowing depth, green manure.

\section{INTRODUCTION}

Lupinus campestris Schltdl. \& Cham. is an annual legume typical of disturbed soils of temperate mountainous regions of the states of Jalisco, Michoacán, México, Morelos, Veracruz and Oaxaca (Dunn, 2001), where it grows forming patches. Untreated seeds of L. campestris

${ }^{1}$ Universidad Autónoma Metropolitana, Unidad Técnica Regional Península, Calle 15 No. 99-K. Col. Itzimná, Mérida Yucatán, CP 97100, México.

${ }^{2}$ Universidad Autónoma Metropolitana, Unidad Xochimilco, División de Ciencias Biológicas y de la Salud, Calzada del Hueso 1100, Col. Villa Quietud. C.P. 04960 México D.F., México. *Corresponding author (fdeleon@correo.xoc.uam.mx).

${ }^{3}$ Colegio de Postgraduados, Instituto de Recursos Naturales, Carretera México-Texcoco km 36.5, Montecillo Estado de México, C.P. 56230, México.

${ }^{4}$ Universidad Nacional Autónoma de México, Centro de Investigaciones en Ecosistemas, Antigua Carretera a Pátzcuaro No. 8701 Col. Ex-Hacienda de San José de La Huerta C.P. 58190 Morelia, Michoacán, México.

Received: 10 August 2009.

Accepted: 05 January 2010. have low germination percentage apparently due to its hard-coated testa (Buirchell and Cowling, 1998). Other species of the genus Lupinus have been reported to exhibit similar behaviour such as L. sparsiflorus Benth. (Anthony, 1991), L. regalis (Persson, 1993), L. texensis Hook. (Parsons et al., 1994), and L. hispanicus Boiss. \& Reut. (Centenera et al., 1999). In contrast, improved domesticated Lupinus species have been reported not to have dormancy (Dracup and Kirby, 1996).

Seed scarification by immersion in $\mathrm{H}_{2} \mathrm{SO}_{4}$ is often used to eliminate barriers delaying germination (Hartmann et al., 2001). In order to prevent damage to the embryo, optimal immersion time must be experimentally determined. In Lupinus species, optimal immersion times ranged from several minutes to hours presumably based upon testa characteristics. Anthony (1991) found that seeds of $L$. sparsiflorus showed high germination after 20 min in $\mathrm{H}_{2} \mathrm{SO}_{4}$ and with a germination temperature range of 10 to $21{ }^{\circ} \mathrm{C}$ (Anthony, 1991). Centenera et al. (1999) observed $97 \%$ germination in L. hispanicus and $67 \%$ of L. hispanicus subsp. bicolor (Merino) Gladst., after $6 \mathrm{~min}$ 
of $\mathrm{H}_{2} \mathrm{SO}_{4}$ immersion. Germination of $L$. arboreus Sims seeds without scarification was $5 \%$, and increased to $80 \%$ after $60 \mathrm{~min}$ in $\mathrm{H}_{2} \mathrm{SO}_{4}$ and also mechanical scarification (cutting the hard seed cover) resulted in germination $>80 \%$ (Mackay et al., 2001). Specific studies about testa characteristics (hardness and thickness) and their relationship to type and time of scarification have not been reported for the Lupinus genus.

Light and darkness have been identified as factors that may influence the effect of scarification. For instance, in a study with 30 plant species from North American alpine conditions (mainly grasses and legumes), Kaye (1997) found that light promoted germination in most species studied. Acosta-Percástegui and Rodríguez-Trejo (2005) found that scarified seeds of $L$. montanus Kunth incubated at $15-20{ }^{\circ} \mathrm{C}$ under light or darkness showed the same germination percentages $(70 \%)$. However when temperature of incubator was increased to $20-30{ }^{\circ} \mathrm{C}$ germination was higher under darkness than under light condition. We therefore hypothesized that interaction of light and scarification would have effect on germination performance in L. campestris.

Martínez-Herrera et al. (2001) reported the presence of quinolizidine alkaloid in stems, leaves, flowers, pods and seeds of L. campestris, this compound probably having allelopathic effects. Robson et al. (2001) found that $L$. albus L. has allelopatic effects, limiting the growth of Spergula arvensis L., Rumex obtusifolius L. and Chenopodium album L.; the authors attribute such effect to the presence of quinolizidine alkaloids in $L$. albus. Some crops such as barley (Hordeum vulgare L.) have been reported to have self-toxicity effects (BenHammouda et al., 2002), and this type of effect could be expected in Lupinus species because alkaloids are present in all plant components. However, this hypothesis has not been tested. Hence the effect of presence or absence of previous Lupinus stands on field establishment was investigated.

Sowing depth may affect seed germination among Lupinus species. Wilson and Thurling (1996), for instance, reported that large seeds of Lupinus can be sowed in a range of 6-9 $\mathrm{cm}$ depth whereas the small seeds are recommended to be sown at $3 \mathrm{~cm}$ depth. In the current study we tested differences in seed germination associated with sowing depth.

Based upon the foregoing discussion, this study was directed to: a) determine the effect of $\mathrm{H}_{2} \mathrm{SO}_{4}$ immersion time and light conditions under laboratory conditions on seed germination of L. campestris; b) evaluate the effects of scarification, sowing depth, and the presence or absence of $L$. campestris plants in plots before the field experiments, on germination and seedling emergence under field conditions.

\section{MATERIALS AND METHODS}

\section{Effect of scarification and light-darkness on seed} germination under laboratory conditions

The experiment was conducted with seeds of Lupinus campestris $2 \mathrm{yr}$ old, which was collected in the locality of Nahuatzen (19³7'28" N; 10153'44” W), Michoacán, México, at 2540 m.a.s.l. Immersion times of 30, 60, 90 or $120 \mathrm{~min}$ in $\mathrm{H}_{2} \mathrm{SO}_{4}$ were evaluated in seeds previously immersed in distilled water for $48 \mathrm{~h}$. One hundred seeds per experimental unit per treatment were germinated under light $\left(0.5 \mu \mathrm{mol} \mathrm{m} \mathrm{m}^{-2} \mathrm{~s}^{-1}\right.$; photosynthetically active radiation, PAR), measured with a sensor mark ELE from 07:00 to 19:30 $\mathrm{h}$ and darkness from de 20:00 to $06: 30 \mathrm{~h}$; and under absolute darkness (on Petri boxes covered with black plastic bags). The experimental design was randomized complete blocks with five replicates per treatment.

Scarification treatment consisted of seed immersion in $\mathrm{H}_{2} \mathrm{SO}_{4}$ for specified times, and immediately they were rinsed with water for $15 \mathrm{~min}$ and seeded on Petri boxes with filter paper and put under light and darkness incubation conditions at $24{ }^{\circ} \mathrm{C}$. Germinated seeds were counted every day for $30 \mathrm{~d}$ after seeding. Seeds were considered germinated when the radicle was $3 \mathrm{~mm}$ long.

Results were analyzed by ANOVA. When differences among treatments were found a Tukey test of homogenous mean groups was performed.

\section{Effect of seed age on seed germination}

It was compared the effect of seed age on seed germination. Seed lots of 1 and $2 \mathrm{yr}$ old were scarified with sulphuric acid $(0,30,60,90$ y $120 \mathrm{~min})$. During the diurnal period seeds received light in the laboratory $\left(0.5 \mu \mathrm{mol} \mathrm{m}^{-2} \mathrm{~s}^{-1}\right)$. For this experiment the same procedures described for the experiment of light-darkness were used.

\section{Effect of scarification, presence-absence of $L$. campestris plants and sowing depth}

The field experiment was conducted in the locality of Casas Blancas (19³7'28” N; 10153'44” W) Pátzcuaro, Michoacán, where annual mean rainfall and temperature are $1100 \mathrm{~mm}$ and $14{ }^{\circ} \mathrm{C}$ respectively. The experimental site is located at elevation 2540 m.a.s.1., in Andisol humic soil $>1 \mathrm{~m}$ depth with stones in the profile, having $5 \%$ inclination. During the last 3 yr before our study, the experimental site was covered mainly with grass and patches of $L$. campestris. Since in the experiment testing the effects of seed age on seed germination we found that $1 \mathrm{yr}$ old seed of L. campestris required less immersion time in acid for germination than $2 \mathrm{yr}$ old seeds (Figure 1), it was decided that $30 \mathrm{~min}$ of acid immersion scarification treatment would be used in the field experiment. 


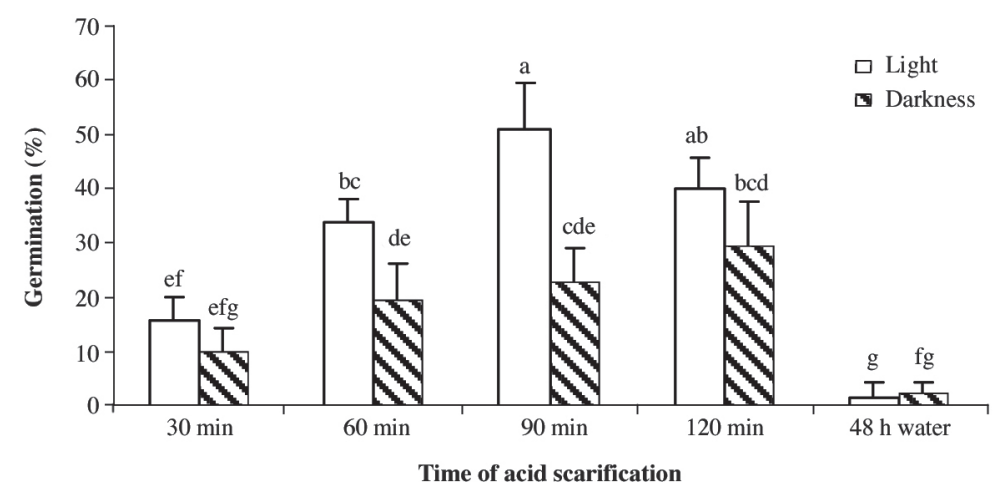

Different letters correspond to different mean groups (Tukey, $\mathrm{P}<0.05$ ).

Figure 1. Germination of Lupinus campestris seeds ( $2 \mathrm{yr}$ old) treated with sulphuric acid, under light and darkness conditions.

Experimental factors were: (a) seed scarification (two levels: scarified and non-scarified seeds); (b) sowing depth (two levels: at soil surface and at $3 \mathrm{~cm}$ underground); (c) presence or absence of L. campestris plants in the site where seeds were sowed (two levels). A total of eight $(2 \times 2 \times 2)$ treatments with six replicates were tested. Experimental units consisted of PVC cylinders (15 $\mathrm{cm}$ diameter; $10 \mathrm{~cm}$ height) buried $8 \mathrm{~cm}$ in the soil and distributed in two circles with a surface of $20 \mathrm{~m}^{2}$ each. A total of 50 seeds of $L$. campestris were sowed per experimental unit (per cylinder). At the beginning of the experiment the grass covering the field was removed with minimal soil disturbance. In the cases where L. campestris was present, only the above ground biomass was removed by cutting the plant at the level of soil surface. Seedlings were considered emerged when the cotyledons appeared above the soil surface and emergence was evaluated 21 $\mathrm{d}$ after sowing. The experimental design was completely randomized with factorial arrangement of treatments.

Data were analyzed by General Linear Model through the SAS program (Martínez, 2005). Means comparison was conducted by a Tukey test (Snedecor and Cochran, 1989).

In order to analyze the soil physical variability, which could influence in seed germination and seedling emergence, soil water content and resistance to penetration was measured and compared in areas of the experimental plot where plants of L. campestris were present and absent just before the experiment, and compared with areas of natural vegetation. Water content was measured by reflectometry $\left(\mathrm{cm}^{3} \mathrm{~cm}^{-3}\right.$; Time Domain Reflectometry, model Trase $6050 \mathrm{X} 1 ; 15 \mathrm{~cm}$ soil depth). Soil resistance to penetration was determined in the $0-15 \mathrm{~cm}$ soil profile; five insertions of a cone penetrometer (digital model Bush) were done in the areas with and without $L$. campestris plants.

\section{RESULTS}

Effect of scarification and light-darkness on seed germination

Seeds immersed $90 \mathrm{~min}$ in sulphuric acid and maintained under diurnal light/darkness showed the highest germination percentage (50\%; Figure 1). Scarification treatments of 30 and $60 \mathrm{~min}$ immersion in acid resulted in a lower germination than that obtained with $90 \mathrm{~min}$ in acid immersion. For scarified seeds that were maintained under complete darkness they had germination percentages that were significantly lower than seeds germinating under diurnal light (Figure 1). Seeds in the control treatment (wetted in distilled water) had very low germination percentage $(<5 \%$; Figure 1$)$. Statistical significances of factor effects are shown on Table 1.

\section{Effect of seed age in seed germination}

In Figure 2 are shown the results of germination percentage for seed lots with 1 and $2 \mathrm{yr}$ old. Seeds of 1 yr old required a shorter scarification time to obtain the maximal germination value (30 $\mathrm{min})$ as compared to 60 min required by 2 yr old seeds. However the regression analysis between seed age (independent variable) and germination (dependent variable) was not significant $(\mathrm{P}$ $>0.05)$.

Effect of scarification, presence-absence of $L$. campestris plants and sowing depth

In field experiments, seeds that were scarified in sulphuric acid had a higher germination percentage and seedling emergence percentages $(\mathrm{P}<0.01$; Table 1$)$ than the nonscarified seeds. Data of seed germination and seedling emergence comparing the effect of seed scarification are showed in Table 2. Presence and absence of plants of $L$. campestris just before the experiment did not influence both 
Table 1. Square means and statistical significance of ANOVA for variables measured at laboratory and field conditions.

\begin{tabular}{llcc}
\hline Experimental factors & df & Germination & $\begin{array}{c}\text { Emergence of } \\
\text { seedlings }\end{array}$ \\
\cline { 3 - 4 } Laboratory & & & - \\
Scarification (S) & 4 & $1787.2 * *$ & - \\
Light (L) & 1 & $1322.5 * *$ & - \\
S x L & 9 & $237.2 * *$ & $18081.39 * *$ \\
Field & & & $2.37 \mathrm{NS}$ \\
Scarification (S) & 1 & $19537.04 * *$ & $1.51 \mathrm{NS}$ \\
Presence of Lupinus campestris (Lc) & 1 & $1.16 \mathrm{NS}$ & $399.38^{*}$ \\
Sowing depth (D) & 1 & $129.85 \mathrm{NS}$ & $45.71 \mathrm{NS}$ \\
Lc x S & 1 & $528.46 *$ & $47.93 \mathrm{NS}$ \\
Lc x D & 1 & $89.60 \mathrm{NS}$ & $64.10 \mathrm{NS}$ \\
Lc x S D D & 2 & & - \\
\hline
\end{tabular}

*Significant $(\mathrm{p} \leq 0.05) ; * *$ highly significant $(\mathrm{p} \leq 0.01)$; NS: non significant.

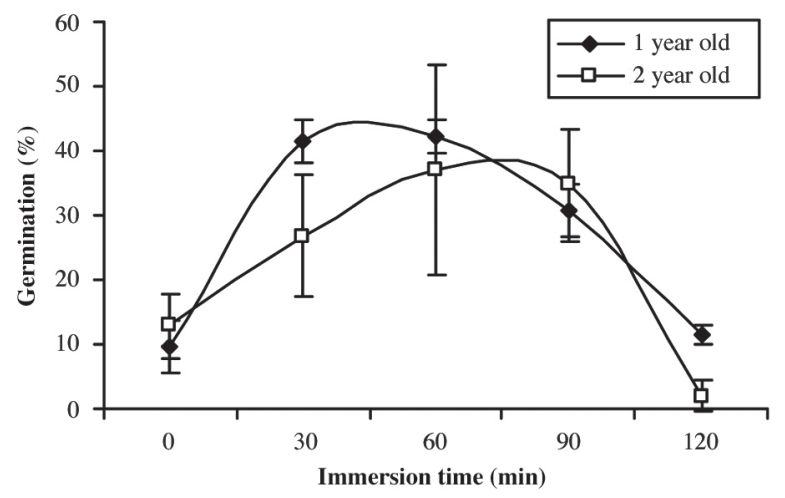

Figure 2. Seed germination as influenced by time of scarification in sulphuric acid and seed age. Means and standard deviations. germination and seedling emergence (Table 1). Sowing seeds on the soil surface or at $3 \mathrm{~cm}$ depth did not have significant effect on germination and seedling emergence percentages (Table 1). In contrast, the interaction between presence-absence of plants of $L$. campestris and seeding depth was significant. However since the main effect for presence/absence of L campestris was no significant this apparent interaction cannot be regarded as reliable (Table 1). A higher percentage of seeds germinated and emerged when planted in a site with plants of L. campestris and at $3 \mathrm{~cm}$ soil depth than when the seeds were planted without plants of L. campestris and at soil surface, for scarified seeds (Table 2). Seeds that were not scarified showed a low germination percentage (Table 2).

The water content and soil strength were similar in the sites with and without plants of L. campestris. The soil water content (measured $20 \mathrm{~d}$ after seeding) in the

Table 2. Means of seed germination and seedling of Lupinus campestris in the field experiment at Casas Blancas, Michoacán. Seed variables were measured 21 d after sowing.

\begin{tabular}{lcccc}
\hline $\begin{array}{l}\text { Seed } \\
\text { scarification }\end{array}$ & $\begin{array}{c}\mathbf{W}^{\mathbf{W}} \begin{array}{c}\text { Sith plants of } \boldsymbol{L} \text {. campestris } \\
\text { before experiment }\end{array} \\
\text { Seeding depth }\end{array}$ & Germination & Seedlings \\
\hline Yes & Yes & cm & & \\
Yes & Yes & $3 \mathrm{~cm}$ & $64.0 \pm 9.38 \mathrm{a}$ & $56.8 \pm 11.79 \mathrm{a}$ \\
Yes & No & Soil surface & $50.0 \pm 8.29 \mathrm{a}$ & $48.7 \pm 8.55 \mathrm{a}$ \\
Yes & No & $3 \mathrm{~cm}$ & $52.0 \pm 11.59 \mathrm{a}$ & $47.3 \pm 13.72 \mathrm{a}$ \\
No & Yes & Soil surface & $8.8 \pm 3.35 \mathrm{~b}$ & $8.8 \pm 3.35 \mathrm{~b}$ \\
No & Yes & $3 \mathrm{~cm}$ & $10.7 \pm 4.84 \mathrm{~b}$ & $6.7 \pm 4.84 \mathrm{~b}$ \\
No & No & Soil surface & $16.0 \pm 5.66 \mathrm{~b}$ & $15.3 \pm 4.68 \mathrm{~b}$ \\
No & No & $3 \mathrm{~cm}$ & $16.0 \pm 0.79 \mathrm{~b}$ & $12.7 \pm 7.76 \mathrm{~b}$ \\
\hline
\end{tabular}

${ }^{1} 90$ min of immersion in sulphuric acid; \pm : standard deviations; same letters correspond to same mean group (Tukey; $\mathrm{P}<0.05$ ). 
area with plants of L. campestris was $32 \pm 1.8)$ vs. 34 $\pm 1 \mathrm{~cm}^{3} \mathrm{~cm}^{-3}$ in the soil without L. campestris. Means of soil resistance to penetration also show a similar pattern in both areas $(1.9 \pm 0.3$ and $1.7 \pm 0.3 \mathrm{MPa}$, respectively; Figure 3 ).

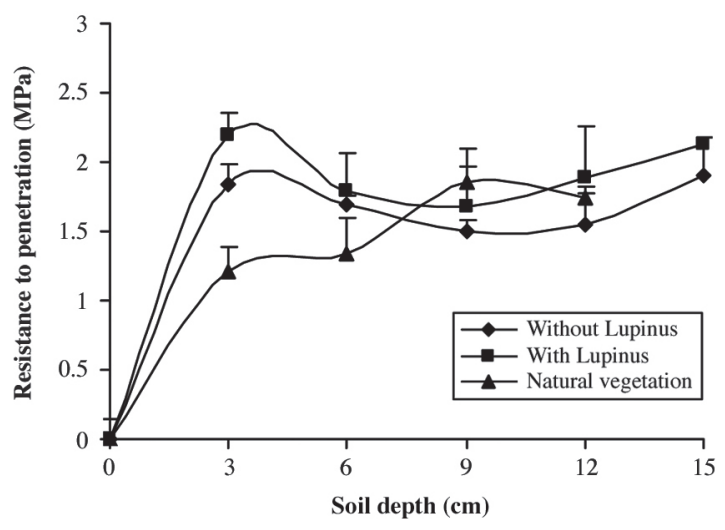

Figure 3. Soil resistance to penetration (MPa). Means and standard errors.

\section{DISCUSSION}

The results of the experiments conducted indicate that seeds of $L$. campestris had a very low germination percentage when they were not submitted to scarification treatment to break dormancy. In the laboratory experiment, germination of untreated seed was lower than $5 \%$ whereas in the field it ranged between 9 and 16\%. Dormancy due to the hard seed coat may be playing a crucial role in the sporadic pattern of $L$. campestris colonizing disturbed areas such as the lateral limits of roads. Medina-Sánchez and Lindig-Cisneros (2005) reported for L. elegans 85\% of germination for seeds recently harvested $(<1 \mathrm{yr})$, whereas in the current work seeds of L. campestris ( 1 and 2 yr old) never reached germination percentages higher than $64 \%$. In wild species it is common to find large differences in seed germination percentage among seeds from the same species but collected in different microsites or years, as Kaye and Kuykendall (2001) reported for $L$. sulphureus subsp. kincaidii. They found germination percentage differences of $40 \%$ between two different seed populations, treated with the same scarification and stratification conditions. Halpern (2005) reported that a fivefold variation in seed size arose primarily from differences among individuals and within-plant variability rather than from environmental conditions manipulated in the experiment.

Results reported here are consistent with those obtained with other wild species of Lupinus. For example, Mackay et al. (2001) observed that non-scarified seeds of L. arboreus had germination lower than $5 \%$ and with immersion in $\mathrm{H}_{2} \mathrm{SO}_{4}$ for 0-60 min increased germination percentage $(80 \%)$. In the current study, seeds of L. campestris scarified with $\mathrm{H}_{2} \mathrm{SO}_{4}$ exhibited almost $50 \%$ of germination. However, with L. arboreus (Mackay et al., 2001) and L. hispanicus (Centenera et al., 1999) the germination was higher than 90\%. AcostaPercástegui and Rodríguez-Trejo (2005) reported that seeds of L. montanus (also from Mexico) scarified with concentrated $\mathrm{H}_{2} \mathrm{SO}_{4}$ in immersions of 15 min resulted in $100 \%$ of germination. Anthony (1991) reported that seed germination of L. sparsiflorus was higher by $\mathrm{H}_{2} \mathrm{SO}_{4}$ scarification (10 and $20 \mathrm{~min}$ immersion) as compared to water washing or giberellic acid applications; the optimal results were obtained by seed immersion in $\mathrm{H}_{2} \mathrm{SO}_{4}$ by 20 min, at $15.6{ }^{\circ} \mathrm{C}$ (Anthony, 1991). These results suggest that seed dormancy in Lupinus is generally better broken by acid treatment as compared to hormonal treatment.

The immersion of L. campestris seeds in water did not improve their germination percentage. Light had a positive effect on germination; the percentage of seed germination was lower under darkness than under light for the four $\mathrm{H}_{2} \mathrm{SO}_{4}$ treatments. Kaye (1997) did not find differences in germination percentage of seeds of $L$. latifolius (var. subalpinus; a wild species) under light or darkness conditions (49\% of germination for both treatments).

Under field conditions, sowing of scarified seeds of L. campestris resulted in a range of $50-64 \%$ of germination and seedling, which were very similar to those obtained in laboratory experiment, but lower than the germination percentages obtained with other species of the genus Lupinus. Kaye and Kuykendall (2001) suggested the simultaneous application of scarification treatments (mechanical or chemical) and stratification by cold treatments was needed to increase seed germination percentage of Lupinus sulphureus subs. kincaidii. The increasing of seed germination by sulphuric acid scarification is an encouraging result for propagation projects of $L$. campestris used as a plant improving soil fertility due to its capacity to fix atmospheric N, and/or for restoration of lands affected by fire.

The seeding depth $(0$ or $3 \mathrm{~cm})$ did not affect the seed germination and seedling emergence. Considering that $L$. campestris is a small-seeded species $(0.5 \mathrm{~cm}$ diameter $)$, our results are in agreement with those reported by Wilson and Thurling (1996) about optimal sowing depth for Lupinus species in Australia.

The occurrence of plants of $L$. campestris in the experimental areas before seed sowing did not affect seed germination. This result suggests that L. campestris does not present self-toxicity as reported for other plant species as pearl millet (Pennisetum glaucum (L.) R.Br.) (Saxena et al., 1996) and barley (Hordeum vulgare L.; 
Ben-Hammouda et al., 2002). Results concerning the two soil control variables (soil water content and soil resistance to penetration) indicated homogeneity in these variables suggesting that the presence-absence of plants of L. campestris did not modify these soil properties in such a form that they could affect the seed germination of L. campestris.

Concerning the effect of seed age a specific study including a larger scale of seed ages is needed. In the current study only two ages ( 1 and 2 yr old) were tested and the correlation between seed age and seed germination was not statistically significant.

Scarified seeds can be sown at soil surface or at 3 $\mathrm{cm}$ soil depth. The last option could reduce the impact of bird predation. Sowing at $3 \mathrm{~cm}$ would also likely be better for germination under relatively dry conditions; i.e. seed sown on the surface would dry relatively quickly compared to seed $3 \mathrm{~cm}$ below the surface.

Studies on L. campestris potential for ecological restoration and agroforestry systems are in an initial step in Mexico (Medina-Sánchez and Lindig-Cisneros et al., 2005). Alvarado-Sosa et al. (2007) investigate the optimal conditions to produce young plants of $L$. elegans in greenhouse and they found that $310 \mathrm{~cm}^{3}$ containers with weekly fertilizer applications $(4,7$, and $4 \mathrm{mg}$ of $\mathrm{N}, \mathrm{P}$ and $\mathrm{K}$, respectively, per plant) were the optimal conditions for the species and seed population. The adequate plant age to transplant them was 3 mo old (Alvarado-Sosa et al., 2007). In the present work it was demonstrated that viable seedlings were obtained under field conditions from scarified seeds. Since germination and seedling emergence are the most vulnerable life stages to plant mortality (Severns, 2003), further studies must quantify juvenile and adult plant performance, and comparing plant survival of seedling obtained in greenhouse or directly field sown.

\section{CONCLUSIONS}

Scarification treatment with sulphuric acid effectively breaks dormancy in L. campestris seeds. Direct sowing of scarified seeds (on the soil surface or at $3 \mathrm{~cm}$ depth) resulted in a range of 50-64\% of germination under field conditions. No evidence was obtained for self-inhibition or a positive interaction between preceding vegetation and seed germination of L. campestris.

\section{ACKNOWLEDGEMENTS}

The National Council of Science and Technology (CONACYT), Mexico, financed the Ph.D. program of Pedro Gutiérrez Nava. Ana Elena Rezéndiz and Erika
Moreno, Agronomy students at Universidad Autónoma Metropolitana (UAM, Xochimilco), cooperated in the laboratory experiment. Authors are grateful to two anonymous reviewers that helped us to improve the manuscript.

\section{RESUMEN}

Efecto de la escarificación, autoinhibición y profundidad de siembra sobre la germinación de semillas de Lupinus campestris. Lupinus campestris Schltdl. \& Cham. crece en campos en descanso y áreas alteradas en el centro de México. Posee potencial para mejorar la fertilidad del suelo y como forraje. Las semillas de L. campestris presentan letargo, y para probar su uso potencial se requiere información sobre las condiciones que favorecen su germinación en condiciones naturales. El objetivo del estudio fue evaluar la germinación de la semilla de L. campestris en condiciones de laboratorio y en campo. En laboratorio, semillas de 2 años de edad tuvieron un máximo de germinación de $50 \%$ cuando fueron escarificadas con ácido sulfúrico durante $90 \mathrm{~min}$ manteniendo luz $(\mu \mathrm{mol}$ $\left.\mathrm{m}^{-2} \mathrm{~s}^{-1}\right)$ durante el período diurno. Sin escarificación, las semillas presentaron una germinación inferior a 3\%. En condiciones de luz se presentó mayor porcentaje de germinación de semillas en comparación con oscuridad. En el experimento de campo se trabajó con semillas de 1 año de edad y consistió de los siguientes tratamientos: (a) escarificación de la semilla (semilla escarificada por $30 \mathrm{~min}$ en ácido sulfúrico, y no escarificada), (b) presencia o ausencia de plantas de L. campestris en las parcelas donde se realizó el experimento, y (c) profundidad de siembra (en la superficie del suelo y a $3 \mathrm{~cm}$ de profundidad). Las semillas escarificadas mostraron un rango de germinación de 50-64\%, y las no escarificadas de 9 a 16\%. En condiciones de campo semillas sembradas en parcelas con o sin plantas de $L$. campestris como vegetación precedente germinaron en forma similar indicando la no existencia de autoinhibición de la germinación. Se concluye que: (1) el tratamiento de escarificación con ácido sulfúrico rompe el letargo de las semillas de L. campestris; (2) la siembra directa de semillas escarificadas (en la superficie del suelo o a $3 \mathrm{~cm}$ de profundidad) produjo un porcentaje de germinación de 50 a $64 \%$ en condiciones de campo y (3) no se observaron evidencias de auto-toxicidad o una interacción positiva entre la vegetación precedente y la germinación de semillas de L. campestris.

Palabras clave: letargo de semilla, abonos verdes, profundidad de siembra. 


\section{LITERATURE CITED}

Acosta-Percástegui, J., and D.A. Rodríguez-Trejo. 2005. Factors affecting germination and pregerminative treatments of Lupinus montanus seeds. Interciencia 30:576-579.

Alvarado-Sosa, P., A. Blanco-García, and R. LindigCisneros. 2007. Test of alternative nursery propagation conditions for Lupinus elegans Kunth plants, and effects on field survival. Revista Fitotecnia Mexicana 30:201-204.

Anthony, R. 1991. Wildflower seed dormancy. Wildflower 4:36-39.

Ben-Hammouda, M., H. Ghorbal, R.J. Kremer, and O. Oueslatt. 2002. Autotoxicity of barley. Journal of Plant Nutrition 25:1155-1161.

Buirchell, B.J., and W.A. Cowling. 1998. Genetic resources in lupins. p. 41-66. In Gladstones, J.S., C.A. Atkins, and J. Hamblin (eds.) Lupins as crop plants: Biology, production, and utilization. $\mathrm{CAB}$ International, Cambridge, UK.

Centenera, E.,C.Dela Cuadra, and G.D.Hill. 1999. Control of seed viability in Lupinus hispanicus. p. 416-419. Proc. $8^{\text {th }}$ International Lupin Conference, Asilomar, California, USA. International Lupin Conference, Guadalajara, Jalisco, Mexico. International Lupin Association, Canterbury, New Zealand.

Dracup, M., and E.J.M. Kirby. 1996. Lupin development guide. 97 p. University of Western Australia Press, Nedlands, Western Australia, Australia.

Dunn, D.B. 2001. Género Lupinus L. [Genus Lupinus L.] p. 290-300. In Rzedowski, G.C., y J. Rzedowski (eds.) Flora fanerogámica del Valle de México. $2^{\mathrm{a}}$ ed. Instituto de Ecología, A.C. y Comisión para el Conocimiento y Uso de la Biodiversidad, Pátzcuaro, Michoacán, México.

Halpern, S. 2005. Sources and consequences of seed size variation in Lupinus perennis (Fabaceae): adaptive and non-adaptive hypotheses. American Journal of Botany 92:205-213.

Hartmann, H.T., D.E. Kester, F.E. Davies, and R. Geneve. 2001. Hartmann and Kesters plant propagation: Principles and practices. 880 p. $7^{\text {th }}$ ed. Prentice Hall, Upper Saddle River, New Jersey, USA.

Kaye, T.N. 1997. Seed dormancy in high elevation plants: implications for ecology and restoration. p. 115120. In Kaye, T.N., et al. (eds.) Conservation and management of native plants and fungi. Native Plant Society of Oregon, Corvallis, Oregon, USA.
Kaye, T.N., and K. Kuykendall. 2001. Effects of scarification and cold stratification on seed germination of Lupinus sulphureus ssp. kincaidii. Seed Science and Technology 29:663-668.

Mackay, W.A., T.D. Davis, and S. Sankhla. 2001. Influence of scarification and temperature on seed germination of L. arboreus. Seed Science and Technology 29:543548.

Martínez, G.G. 2005. Introducción al SAS. 164 p. Colegio de Postgraduados, Montecillos, México.

Martínez-Herrera, J., N. Robledo-Quintos, R. MoraEscobedo, and G. Dávila-Ortíz. 2001. Alkaloid composition of Lupinus campestris from Mexico. Journal of Food Biochemistry 25:117-125.

Medina-Sánchez, E., and R. Lindig-Cisneros. 2005. Effect of scarification and growing media on seed germination of Lupinus elegans H.B.K. Seed Science and Technology 33:237-241.

Parsons, J.M., T.D. Davis, S.W. George, and A. Mackay. 1994. Barbara Bush' bluebonnet (Lupinus texensis Hook). HortScience 29:1202.

Persson, B. 1993. Enhancement of seed germination in ornamental plants by growth regulators infused via acetone. Seed Science and Technology 21:281-290.

Robson, M.C., D. Robinson, A.M. Litterick, C. Watson, and M. Leitch. 2001. Investigations into allelopathic interactions of white lupin (Lupinus albus). British Crop Protection Council Conference (Weeds), Brighton, UK. 12-15 November. Vol. 1 and Vol. 2. British Crop Protection Council, Alton, Hampshire, UK.

Saxena, A., D.V. Singh, and L.N. Joshi. 1996. Autotoxic effects of pearl millet aqueous extracts on seed germination and seedling growth. Journal of Arid Environments 33:255-260.

Severns, P. 2003. Propagation of a long-lived and threatened prairie plant, Lupinus sulphureus ssp. kincaidii. Restoration Ecology 11:334-342.

Snedecor, G.W., and W.G. Cochran. 1989. Statistical methods $8^{\text {th }}$ ed. Iowa State University Press, Ames, Iowa, USA.

Wilson, C.E., and N. Thurling. 1996. Effect of sowing depth and water potential on seedling emergence of Lupinus species. Australian Journal of Experimental Agriculture 36:463-471. 